\title{
Congenital lipoid adrenal hyperplasia in twin sisters
}

\author{
Hye Won Park', Byung Ok Kwak', Han-Wook Yoo², Sochung Chung ${ }^{1 *}$ \\ From 7th APPES Biennial Scientific Meeting \\ Nusa Dua, Bali. 14-17 November 2012
}

Congenital lipoid adrenal hyperplasia (CLAH) is the most severe form of congenital adrenal hyperplasia that caused by mutations in the steroidogenic acute regulatory protien (StAR). The mutations in StAR gene resulted in failure of the transport cholesterol into mitochondria for steroidogenesis in adrenal gland.

Twin sisters (A, B) were born on $36^{+2}$ gestational week premature to nonrelated parent. Both patient $\mathrm{A}$ and $\mathrm{B}$ were phenotypic female with normal 46, XX genotype. They had symptoms as hyperpigmentation, slightly elevated potassium level and lower level of sodium without severe adrenal insufficiency symptoms. Laboratory finding reveals normal 17 hydroxyprogesterone level, elevated ACTH (A: $4379.2 \mathrm{pg} / \mathrm{ml}, \mathrm{B}: 11616.1$ ), high plasma renin activity (A: $49.02 \mathrm{ng} / \mathrm{ml} / \mathrm{hr}, \mathrm{B}: 52.7 \mathrm{ng} \mathrm{ml} / \mathrm{hr}$ ). However, the level of plasma cortisol before treatment were normal $(7.11 \mu \mathrm{g} / \mathrm{dL})$ in patient $\mathrm{A}$, but low $(1.5 \mu \mathrm{g} / \mathrm{dL})$ in patient $\mathrm{B}$.

Patient A was readmitted with adrenal insufficiency symptoms at 38 days of age with concomitant infection which was suggestive of CLAH and prompted us to process a gene analysis and treatment was started in both. The results of gene analysis of StAR in twin revealed same heterozygous conditions for the c.544C $>\mathrm{T}$ (Arg182Cys) in exon 5 and c.722C $>\mathrm{T}\left(\mathrm{Gln} 258^{*}\right)$ in exon 7.

We report a case of congenital lipoid adrenal hyperplasia showed different cortisol level in genotypic female twin with same StAR gene mutations.

\section{Authors' details}

'Department of Pediatrics, Konkuk University Medical Center, Konkuk University School of Medicine, Korea. ${ }^{2}$ Department of Pediatrics,University of Ulsan, College of Medicine, Children's Hospital, Asan Medical Center Seoul, Korea.

Published: 3 October 2013

'Department of Pediatrics, Konkuk University Medical Center, Konkuk University School of Medicine, Korea

Full list of author information is available at the end of the article
doi:10.1186/1687-9856-2013-S1-P113

Cite this article as: Park et al:: Congenital lipoid adrenal hyperplasia in twin sisters. International Journal of Pediatric Endocrinology 2013 2013(Suppl 1):P113.
Submit your next manuscript to BioMed Central and take full advantage of:

- Convenient online submission

- Thorough peer review

- No space constraints or color figure charges

- Immediate publication on acceptance

- Inclusion in PubMed, CAS, Scopus and Google Scholar

- Research which is freely available for redistribution
() Biomed Central 